Indonesian Journal of Electronics and Instrumentation Systems (IJEIS)

Vol.9, No.2, October 2019, pp. 151 160

ISSN (print): 2088-3714, ISSN (online): 2460-7681

DOI: https://doi.org/10.22146/ijeis.49198

\title{
Desain Kontrol Sistem Telemetri pH Larutan Nutrisi Hidroponik Berbasis Fuzzy Logic
}

\author{
Muhtar*1, Zulmiftah Huda $^{2}$ \\ ${ }^{1,2}$ Prodi Teknik Elektro, Fakultas Teknik dan Teknologi, \\ Universitas Tanri Abeng, Indonesia \\ e-mail: *1'muhtar@tau.ac.id, ${ }^{2}$ zulmiftah.h@gmail.com,
}

\begin{abstract}
Abstrak
Pemanfaatan lahan kosong seperti area sempit, atap gedung, gudang yang tidak terpakai dapat dimaksimalkan sebagai lahan pertanian yaitu dengan sistem pertanian secara hidroponik. Nutrisi pada tanaman merupakan pengganti tanah yang berhubungan dengan namanya derajat keasaman ( $\mathrm{pH}$ ) air, $\mathrm{pH}$ berpengaruh daya larut unsur hara untuk kesuburan tanaman. Pada kenyataan nilai pH nutrisi dalam tangki selalu berubah disebabkan berbagai faktor seperti media tanam. Suhu larutan nutrisi mempengaruhi proses penyerapan ion nutrisi oleh akar tanaman. Suhu terlalu tinggi menyebabkan berkurangnya kemampuan akar tanaman menyerap air dan ion nutrisi. Perkembangan teknologi yang semakin maju, maka pertanian bisa dikendalikan otomatis dan dipantau dari jarak jauh. Di dalam penelitian ini bertujuan membuat desain kontrol pH, volume dan suhu larutan nutrisi dengan fuzzy logic dan komunikasi zigbee pro untuk aplikasi pengendalian jarak jauh pada tanaman hidroponik. Berdasarkan hasil eksperimen menggunakan metode logika fuzzy efektif untuk mengendalikan pH di dalam hidroponik NFT. Waktu yang diperlukan menuju setting point dari pH 5 ppm ke pH 7 ppm sebesar 429 detik dan pH 9 ppm ke pH 7 ppm sebesar 459 detik.
\end{abstract}

Kata kunci-hidroponik, pH, telematika, fuzzy logic

\begin{abstract}
The utilization of bare areas like narrow tract, building roof, or unused warehouse can be maximized as agricultural land using hydroponics system. Hydroponics is a cultivation technique by using nutrient solution. The plant nutrient is an alternative soil which relate with water acidity $(p H)$, that has reaction with nutrient solubility to plant fertility. In fact, $p H$ of the nutrients can change because of many factors like media of plant. The temperature of nutrient solution affect an ion nutrient absorption by plant root. The higher temperature reduces plant root ability to absorb water and ion nutrients. The more advanced technological developments, the agriculture can be controlled automatically and monitored remotely. The aim of this research is to make design control ph, volume and nutrients solution using fuzzy logic and zigbee pro communication for telematics control of plant hydroponics. The result of this experiment shown that fuzzy logic has effectiveness to control $\mathrm{pH}$ of hydroponics. It needs 429 seconds to setting point of range pH 5 ppm to 7 ppm and 459 seconds to setting point of range pH 9 ppm to 7 ppm.
\end{abstract}

Keywords-hyroponic,pH, telematics, fuzzy logic

Received September $1^{\text {st }}, 2019$; Revised October 10 ${ }^{\text {th }}$, 2019; Accepted October 14 ${ }^{\text {th }}, 2019$ 


\section{PENDAHULUAN}

Indonesia merupakan negara agraris yang sebagian besar penduduknya ber profesi di pertanian. Sektor pertanian menjadi sangat penting, di mana laju pertumbuhan penduduk yang tidak seimbang dengan luas lahan pertanian yang sudah ada. Dengan area pertanian yang mulai menyempit maka muncul inovasi - inovasi untuk pengembangan bidang pertanian. Khususnya di kawasan perkotaan, pemanfaatan lahan kosong seperti atap gedung, lantai basement, gudang yang tidak terpakai dapat dimaksimalkan sebagai lahan pertanian yaitu dengan sistem pertanian secara hidroponik [1].

Hidroponik adalah teknik budidaya menggunakan larutan nutrisi. Ini menawarkan banyak manfaat seperti kemampuan untuk menggunakan kembali air dan nutrisi, pengendalian lingkungan yang mudah, dan pencegahan penyakit dan hama yang menular melalui tanah. Bisa diimplementasikan di dalam maupun di luar ruangan [2].

Nutrisi pada tanaman berhubungan dengan namanya derajat keasaman $(\mathrm{pH})$ air, $\mathrm{pH}$ berpengaruh daya larut unsur hara untuk kesuburan tanaman. Pada kenyataan nilai $\mathrm{pH}$ nutrisi dalam tangki selalu berubah disebabkan berbagai faktor seperti media tanam [3]. Suhu larutan nutrisi mempengaruhi proses penyerapan ion nutrisi oleh akar tanaman. Suhu terlalu tinggi menyebabkan berkurangnya kemampuan akar tanaman menyerap air dan ion - ion nutrisi, untuk tanaman sayuran suhu larutan nutrisi antara $5^{\circ} \mathrm{C}-15^{\circ} \mathrm{C}$ [4]. Volume air larutan nutrisi di tangki juga perlu diperhatikan, dikarenakan air mengalir terus dan mengalami penguapan.

Penelitian sebelumnya diantaranya berupa monitoring beberapa data sensor untuk tanaman pertanian dengan menggunakan xbee dan monitoring labview [5]. Sistem Otomatisasi Pengontrolan Volume dan pH Air pada Hidroponik [6], Implementasi Fuzzy Logic Controller untuk Mengatur pH Nutrisi pada Sistem Hidroponik Nutrient Film Technique (NFT) [3] dan Monitoring dan Kontrol Nutrisi pada Sistem Hidroponik NFT Berbasis Konduktivitas Elektrik [7].

Pemantauan dan pengendalian parameter tanaman hidroponik masih membutuhkan suatu sistem yang dapat bekerja maksimal secara otomatis untuk mengendalikan larutan nutrisi $\mathrm{pH}$ yang dapat dipantau dari jarak jauh.-Dengan pengontrolan larutan nutrisi secara otomatis dan pemantauan secara jarak jauh maka diharapkan dapat memudahkan bagi manusia.

Dalam penelitian ini, logika fuzzy dapat mengatasi ketidakjelasan interinsik pemikiran manusia dan bahasa alam dan mengenali sifatnya yang berbeda dari keacakan. Dengan menggunakan algoritma logika fuzzy, mesin digunakan untuk memahami dan merespon konsep manusia yang tidak jelas seperti panas, dingin, besar, kecil, dan lain - lain [8]. Tanaman hidroponik yang dikontrol dalam penelitian adalah tanaman pakchoy / sawi sendok. Dari berbagai macam sawi, pakchoy termasuk yang banyak dibudidayakan petani saat ini. Kelebihan lain sawi pakchoy yaitu mampu tumbuh baik di dataran rendah maupun dataran tinggi [9].Pertumbuhan sawi yang baik memerlukan $\mathrm{pH}$ sebesar 7.0 [10].

\section{METODE PENELITIAN}

Pelaksanaan penelitian dimulai dari konsep berkunjung ke masyarakat yang mempunyai tanaman hidroponik, perancangan alat, perancangan perangkat keras, perancangan perangkat lunak dan algoritma , hingga tahap pengujian pengiriman data dan pengontrolan. Pembuatan perangkat keras (hardware) dilakukan sebelum membuat program agar dapat mempermudah dalam melakukan pengecekan apabila terjadi kesalahan. Apabila seluruh desain selesai dilaksanakan, maka dapat dilakukan kalibrasi dan validasi terhadap alat yang dibuat. Kemudian dapat dilakukan pengujian alat, pengujian pengiriman data, dan pengujian alat dengan 
menggunakan tanaman pakchoi. Gambar 1 merupakan flowchart pelaksanaan penelitian dimulai dari konsep perancangan hingga tahapan uji coba alat.
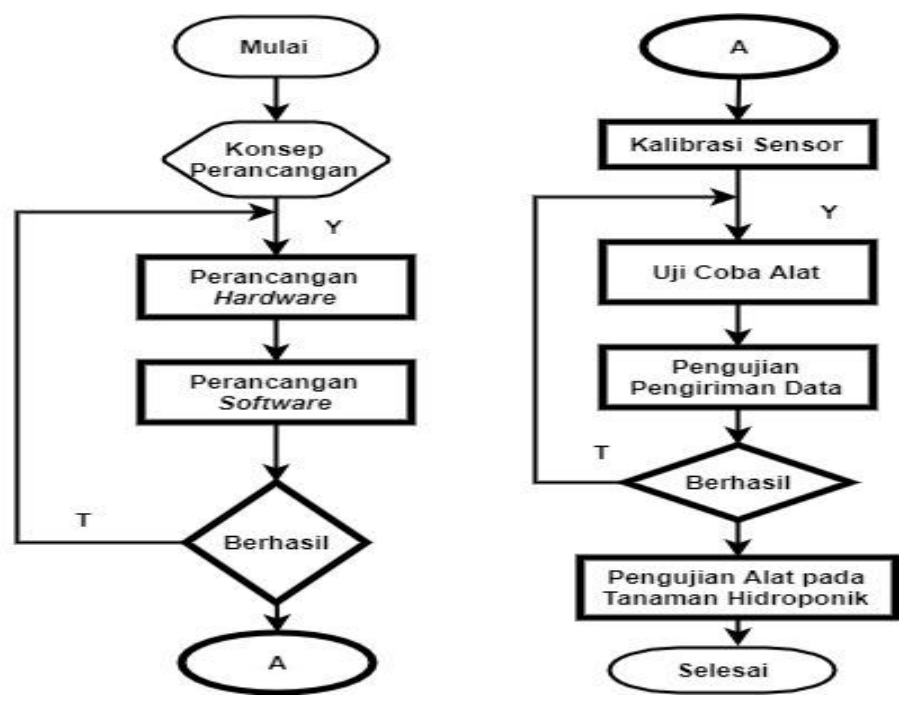

Gambar 1 Flowchart pelaksanaan penelitian

\subsection{Sistem Secara Umum}

Pada bab ini akan dibahas perancangan dan realisasi dari perangkat keras dan perangkat lunak sistem telemetri suhu dan kelembaban untuk pola cocok tanam hidroponik. Untuk blok diagram secara umum, dapat dilihat pada Gambar 2.

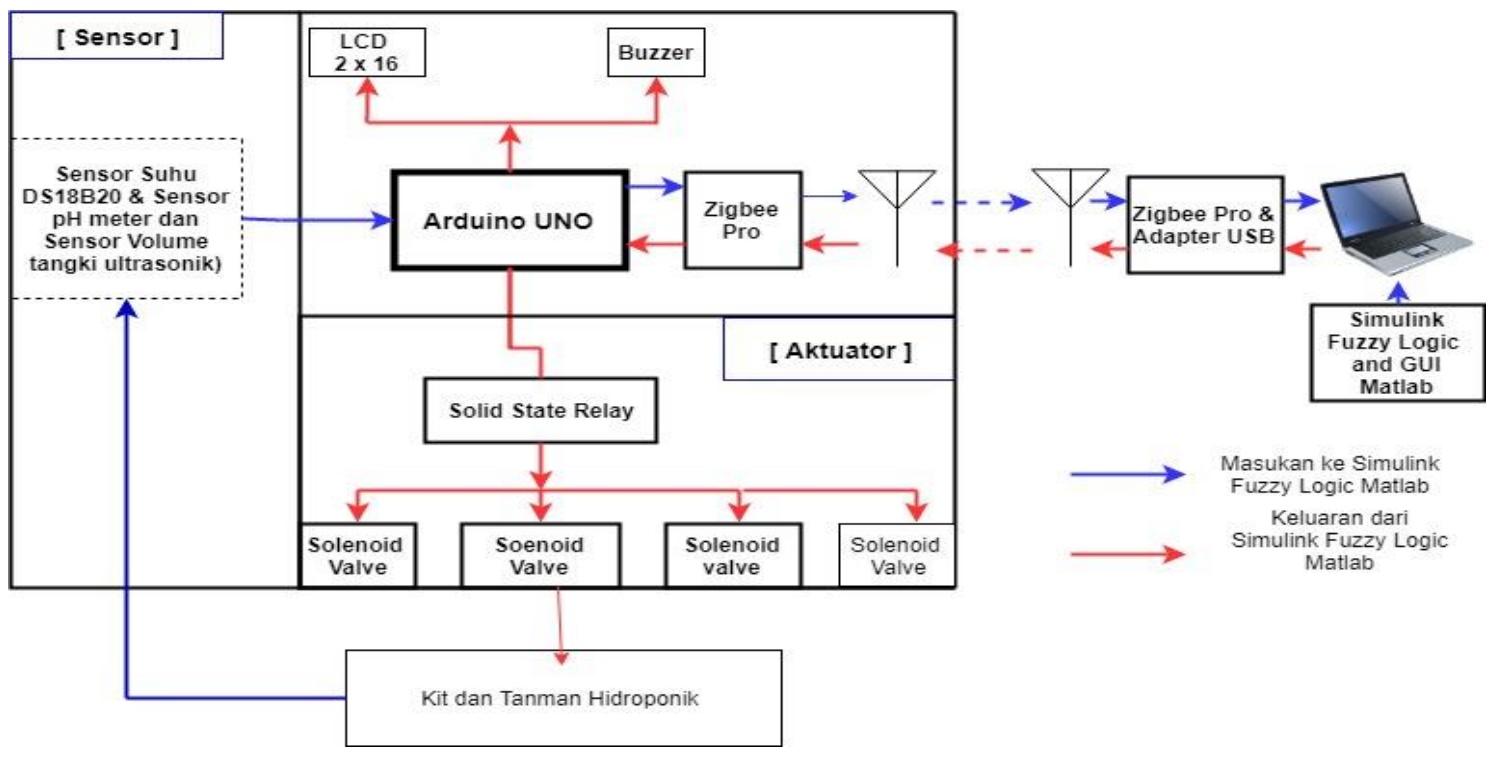

Gambar 2 Blog diagram sistem

Cara kerja sistem secara umum berdasarkan pada blok diagram Gambar 2 adalah sebagai berikut :

1. Seluruh kinerja dari sistem dikendalikan oleh pengendali yang bekerja sesuai dengan perintah yang dikendalikan di algoritma perangkat lunak. 
2. Perangkat system akan membaca besaran fisis diantaranya $\mathrm{pH}$ larutan nutrisi dan isi / volume di dalam wadah melalui sensor - sensor. Data yang didapatkan, akan ditampilkan di simulink matlab dan display ( LCD ).

3. Arduino Uno berfungsi sebagai media perantara untuk mentransmisikan data yang masuk ke PC yang dipancarkan oleh XBee Pro dan juga sebagai tempat pengontrolan aktuator.

4. XBee Pro merupakan transmitter wireless yang beroperasi pada band frekuensi 2,4 GHz. Alat ini mempunyai 2 fungsi yaitu pengirim data dari hasil sensor melalui arduino mega ke PC dan penerima data di PC secara wireless.

5. Setelah data diterima di PC, data tersebut dipisahkan untuk setiap format datanya kemudian datanya akan dibandingkan dengan set point yang ada di simulink matlab sebelum masuk ke program Fuzzy Logic Controller, keluaran dari Fuzzy Logic Controller dikirimkan ke arduino yang di pakai untuk mengendalikan gerakan aktuator solenoid valve.

a) Jika data $\mathrm{pH}$ yang diambil < set point, maka sistem akan mengaktifkan solenoid valve nutrisi up dan apabila suhu > set point, maka sistem akan menyalakan solenoid valve nutrisi down.

\subsection{Driver AC Solenoid Valve}

Di dalam menggerakkan solenoid valve $\mathrm{pH}$ up dan down menggunakan rangkaian optocoupler dan triac BT139 sebagai switching. Prinsip kerja rangkaian pada gambar adalah dengan memanfaatkan suatu masukan arus searah $15 \mathrm{~mA}$ untuk menghidupkan LED MOC3021. Sinyal pemicuan dari mikrokontroler yang berupa pulsa high selama waktu tertentu akan mengalirkan arus ke dalam komponen LED dari MOC3021. Selanjutnya LED akan mengaktifkan output yaitu triac. Akibatnya triac BT139 akan terpicu sehingga aktuator akan teraliri arus listrik. Dengan diaturnya waktu pemberian sinyal pemicuan maka besarnya tegangan yang diterima aktuator juga akan bervariasi. Keuntungan penggunaan rangkaian ini adalah lebih terjaminnya keamanan rangkaian pengendali dari pengaruh jala-jala listrik. Hal ini disebabkan terpisahnya aliran arus antara beban dengan rangkaian pengendali oleh penggandeng cahaya di dalam MOC3021.

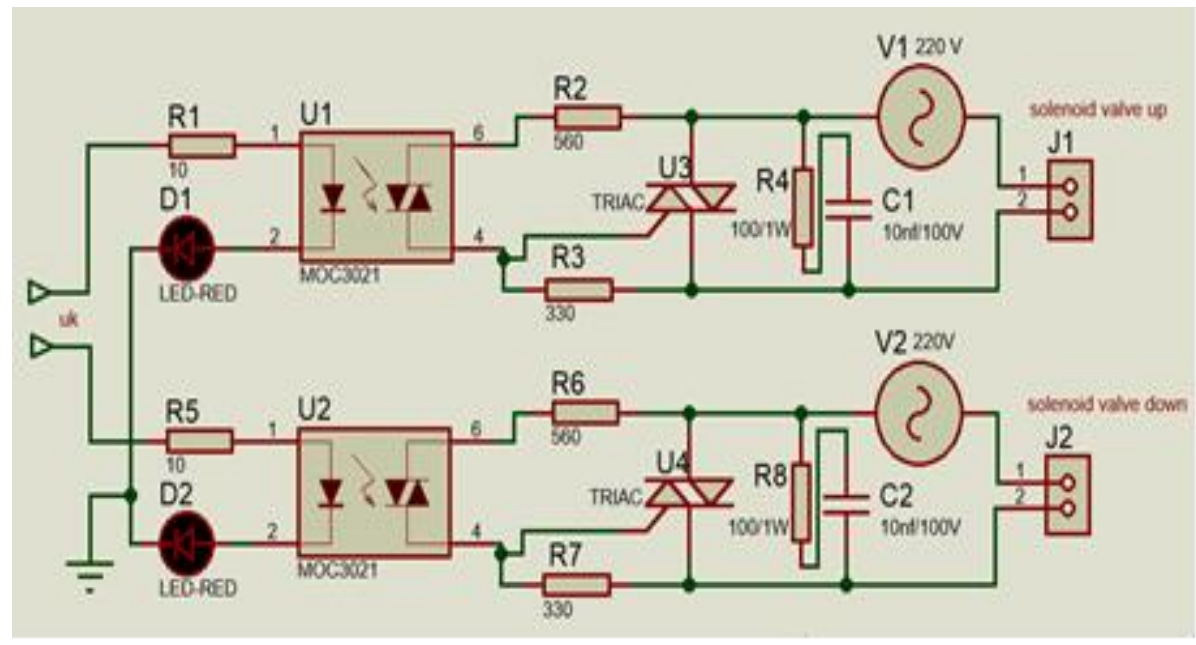

Gambar 3 Rangkaian pengontrol tegangan AC

\section{$2.4 \quad$ Perancangan Fuzzy Logic Control}

Sistem kendali yang di rancang menggunakan fuzzy logic control pada toolbox matlab metode mamdani, untuk sistem perancangan pengendalian $\mathrm{pH}$ menggunakan dua buah input yang masuk ke dalam pengendali fuzzy yaitu error dan delta error. Kemudian variabel output yang akan dihasilkan dari pengendali fuzzy adalah $U(t)$ seperti pada Gambar 4 


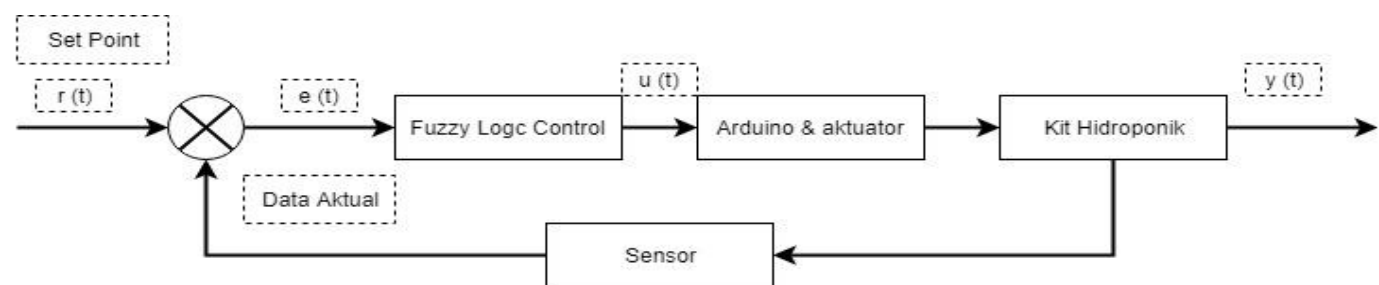

Gambar 4 Diagram alir kendali fuzzy logic

Dalam sistem yang di rancang ini, pengendali di bagian masukan dan keluaran fuzzy logic controller bisa digambarkan pada Gambar 5. Di dalam masukan fuzzy logic terdiri 2 algoritma yaitu sistem error dan delta error.

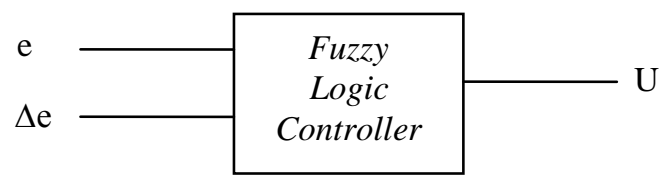

Gambar 5 Input dan output pengendali fuzzy

Error didefinisikan:

$$
e(t)=r(t)-y(t)
$$

Sedangkan delta error didefinisikan:

$$
\Delta e(t)=e(t)-e(t-1)
$$

Adapun sistem kerja dari fuzzy logic ini adalah nilai masukan terdiri dari 2 yaitu error dan delta error dari pembacaan data sensor $\mathrm{pH}$ yang akan dibandingkan dengan nilai setting point sebesar 7. Hasil dari perbandingan tersebut akan di olah oleh fuzzy logic controller.

Fungsi keanggotaan dari fuzzy logic di matlab bisa terlihat pada Gambar 6.

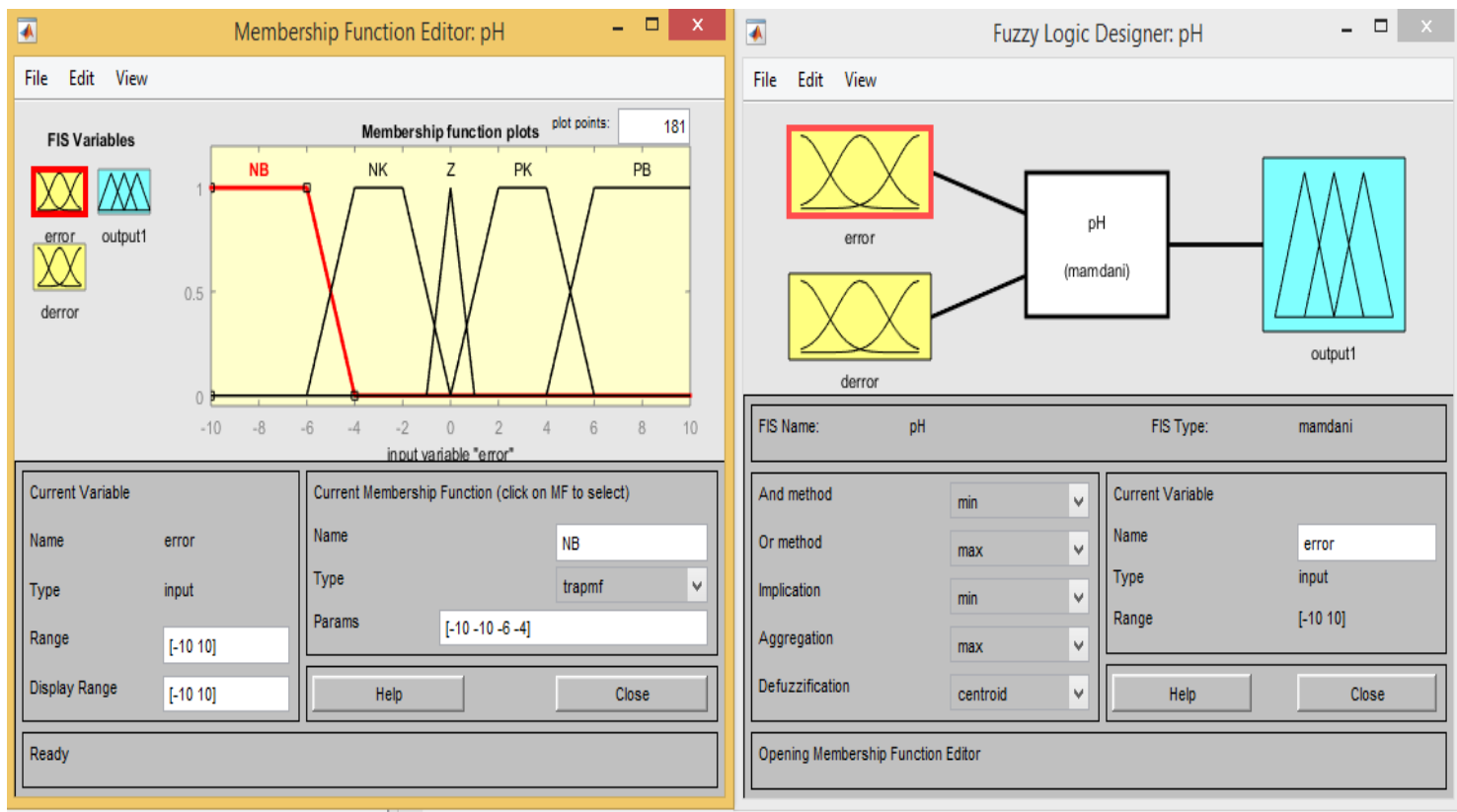

Gambar 6 input / output FLC

Fungsi keanggotaan dari input dan output seperti pada Gambar 4, keanggotaan input ( error ) terdiri dari 5 membership function yaitu Negatif Besar ( NB ), Negatif Kecil ( NK ), Zero ( Z ), Postif Kecil ( PK ) dan Positif Besar ( PB ). Keanggotaan input deerror terdiri NB1, NK1, Z1, PK1 dan PK2. Keanggotaan ouput terdiri dari diam, sedang dan lama. Rule base yang digunakan pada sistem ini seperti pada Gambar 7 yang terdiri dari 15 algoritma. 


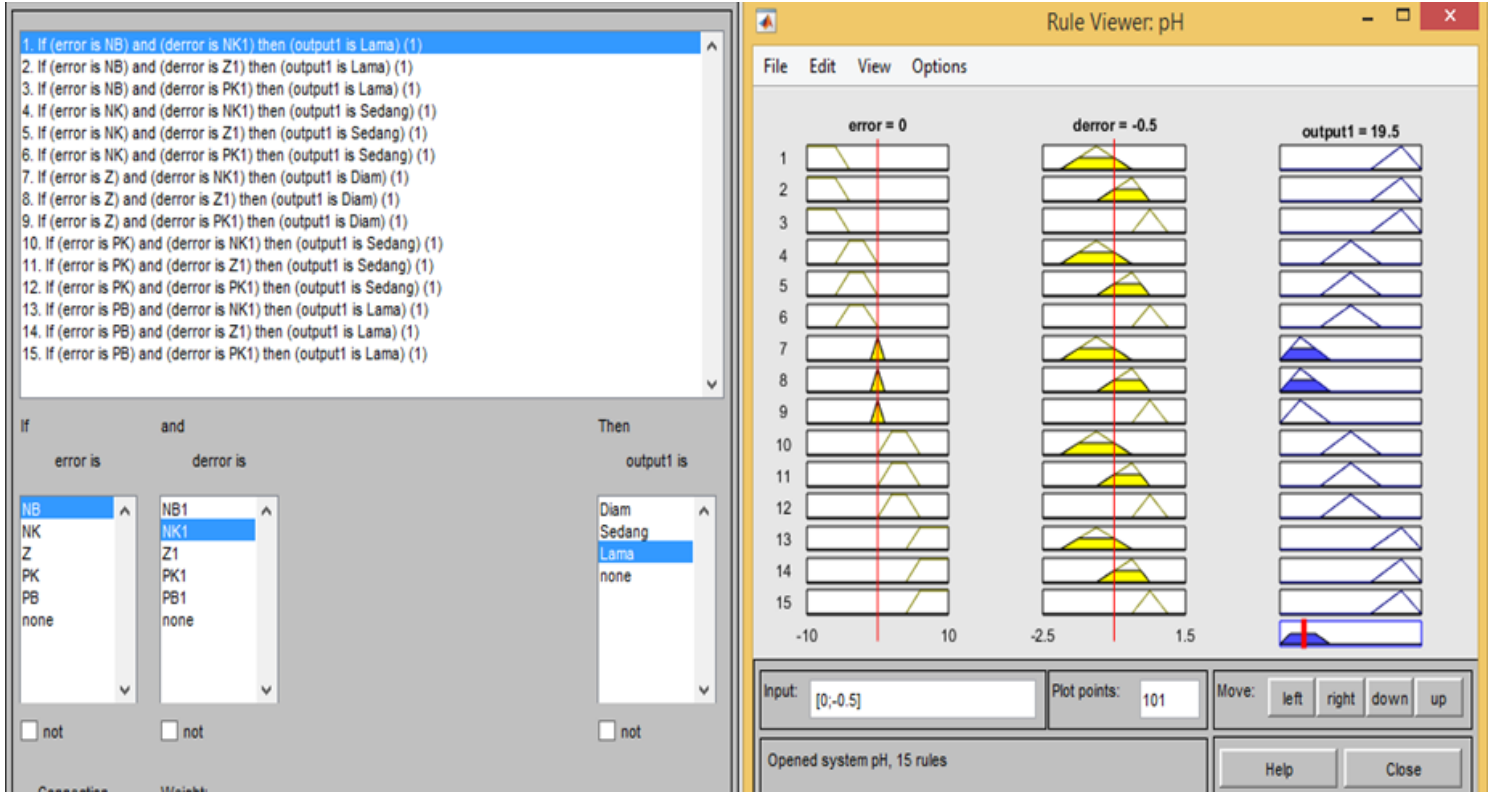

Gambar 7 Aturan FLC

\subsection{Perancangan Algoritma Perangkat Lunak}

Secara sederhana, sensor mengambil data lapangan dan diinisilisasi masukan oleh arduino. Selanjutnya data masukan yang terbaca oleh arduino dikirimkan xbee transmitter dan diterima oleh xbee receiver yang ada di laptop.
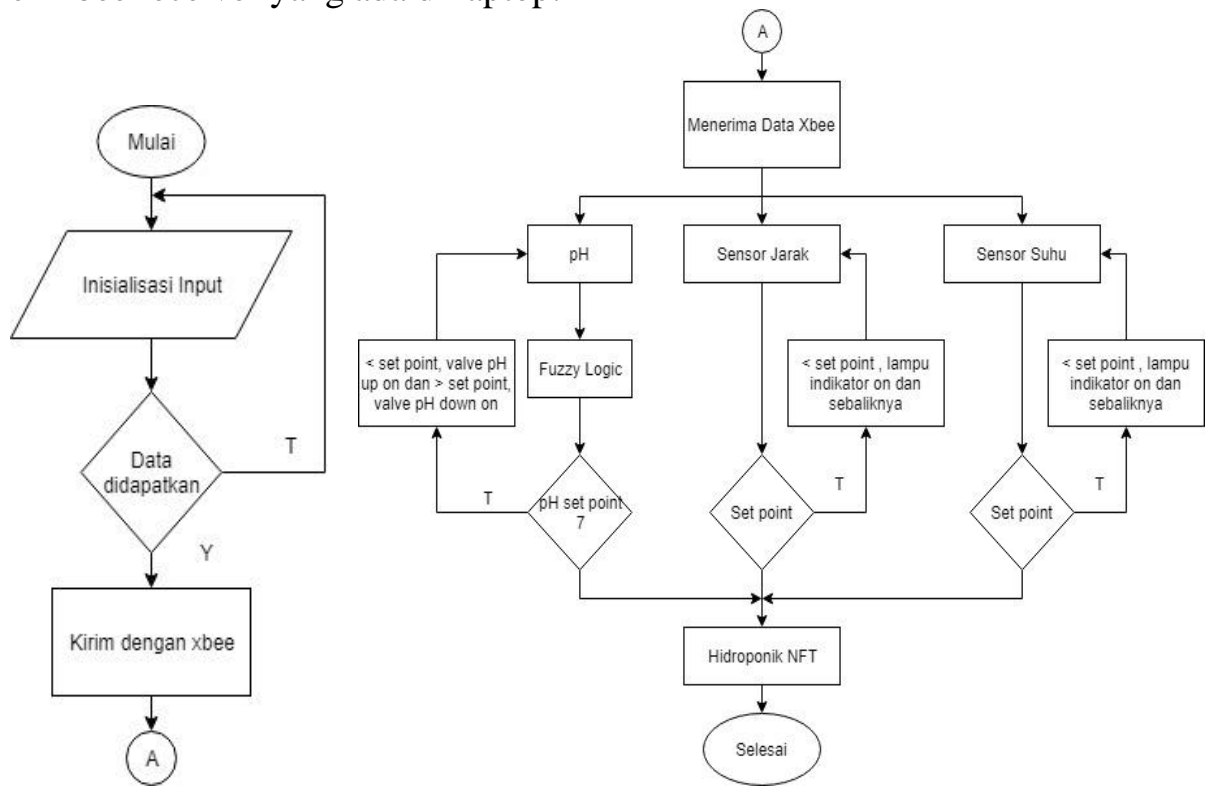

Gambar 8 Diagram alir perangkat lunak

\section{HASIL DAN PEMBAHASAN}

\subsection{Pengujian Setiap Blok}

Sebelum melaksanakan pendataan pada rangkaian terlebih dahulu memeriksa hubungan-hubungan pada rangkaian. Langkah selanjutnya adalah menentukan test point untuk pengujian pada rangkaian yang akan di data. Adapun proses pengujian yang dilakukan adalah sebagai berikut : 


\subsubsection{Pengukuran Jarak Komunikasi Zigbee Pro S2B}

Di dalam pengukuran jarak komunikasi antara Zigbee Pro S2B transmitter dengan receiver digunakan untuk mengetahui seberapa jauh data dapat diterima dengan baik. Pengukuran dilakukan di dua tempat yang berbeda yaitu di tempat terbuka dan di tempat tertutup. Adapun hasilnya seperti di tabel 1 dan 2

Tabel 1 Hasil pengukuran komunikasi antar zigbee pro outdoor untuk waktu 60 detik

\begin{tabular}{|c|c|c|}
\hline No. & Jarak $(\mathrm{m})$ & Status Komunikasi \\
\hline 1 & 10 & Stabil \\
\hline 2 & 20 & Stabil \\
\hline 3 & 30 & Stabil \\
\hline 4 & 40 & Stabil \\
\hline 5 & 50 & Stabil \\
\hline 6 & 60 & Stabil \\
\hline 7 & 70 & Stabil \\
\hline 8 & 80 & Stabil \\
\hline 9 & 90 & Stabil \\
\hline 10 & 100 & Stabil \\
\hline 11 & 110 & Stabil \\
\hline 12 & 120 & Stabil \\
\hline 13 & 130 & Stabil \\
\hline 14 & 140 & Stabil \\
\hline 15 & 150 & Stabil \\
\hline 16 & 160 & Stabil \\
\hline 17 & 170 & Stabil \\
\hline 18 & 180 & Stabil \\
\hline 19 & 190 & Tidak Stabil \\
\hline 20 & 200 & Error \\
\hline
\end{tabular}

Tabel 2 Hasil pengukuran komunikasi antar zigbee pro indoor untuk waktu 60 detik

\begin{tabular}{|c|c|c|}
\hline No. & Jarak $(\mathrm{m})$ & Status Komunikasi \\
\hline 1 & 10 & Stabil \\
\hline 2 & 20 & Stabil \\
\hline 3 & 30 & Stabil \\
\hline 4 & 40 & Kurang Stabil \\
\hline
\end{tabular}

Dari tabel di atas, pengukuran di alam terbuka didapatkan jarak monitoring sampai 180 meter, data dapat diterima dengan baik / stabil. Ketika memasuki jarak di atas $180 \mathrm{~m}$, penangkapan sinyal data mulai berkurang / melemah. Pengukuran ini dilakukan tanpa adanya gedung besar yang menghalangi, sedangkan di alam tertutup yang banyak bangunan hanya mampu sampai 30 meter data dapat diterima.

\subsubsection{Pengujian Rangkaian Pengatur Tegangan AC}

Pada pengujian pengontrol tegangan AC dilakukan dengan cara memberi nilai sinyal kontrol bervariasi dari $0-100 \%$. Pengujian dilakukan dengan menggunakan rangkaian zero crossing detector dan sistem mikrokontroler arduino. 
Tabel 3 Pengaruh perubahan pemberian nilai sinyal kontrol terhadap tegangan pada beban

\begin{tabular}{|c|c|c|}
\hline No. & Nilai Kontrol (\%) & Tegangan Beban (VAC) \\
\hline 1 & 00 & 2 \\
\hline 2 & 10 & 14 \\
\hline 3 & 20 & 30 \\
\hline 4 & 30 & 64 \\
\hline 5 & 40 & 98 \\
\hline 6 & 50 & 130 \\
\hline 7 & 60 & 163 \\
\hline 8 & 70 & 192 \\
\hline 9 & 80 & 214 \\
\hline 10 & 90 & 226 \\
\hline 11 & 100 & 230 \\
\hline
\end{tabular}

Berdasarkan data tabel diatas terlihat bahwa semakin besar nilai sinyal kontrol diberikan maka semakin besar pula tegangan pada beban AC. Hal ini dikarenakan sinyal kontrol tersebut digunakan untuk mengisi nilai pada layanan timer. layanan timer tersebut yang akan digunakan untuk memberikan nilai waktu tunda pemicuan pada triac. Jika sinyal kontrol yang dimasukkan $0 \%$ maka nilai waktu tunda pemicuan triac yang diberikan $10 \mathrm{~ms}$ sehingga tegangan pada beban $2 \mathrm{Vac}$, sedangkan jika sinyal kontrol yang diberikan 100\% maka nilai waktu tunda pemicuan yang diberikan $0 \mathrm{~ms}$ sehingga beban akan memperoleh tegangan maksimal 230 Vac. Di dalam pengujian pengaturan tegangan AC digunakan lampu sebagai gantinya solenoid valve.

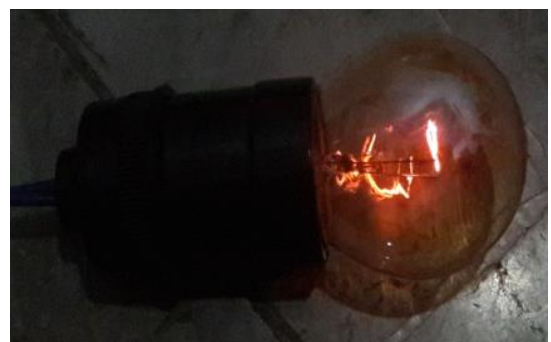

Gambar 9 Sinyal kontrol $10 \%$

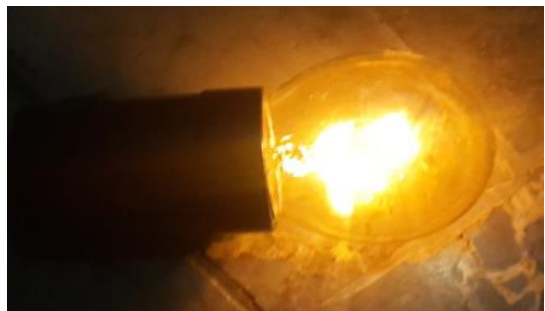

Gambar 11 Sinyal kontrol 60\%

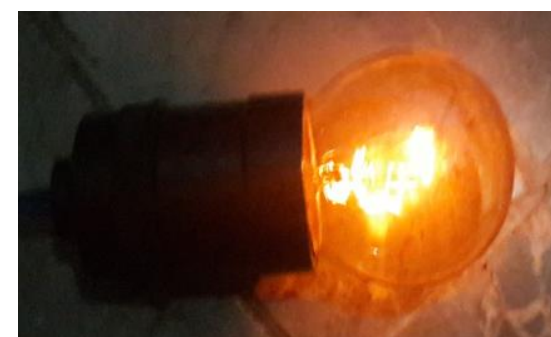

Gambar 10 Sinyal kontrol 20\%

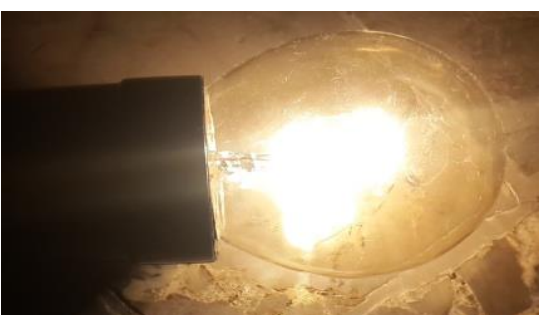

Gambar 12 Sinyal kontrol 90\%

Terlihat dari Gambar 9 sampai 12 ketika sebuah lampu diberikan sinyal kontrol yang semakin besar maka sinyal yang dipancarkan semakin terang. Hal ini digunakan untuk menstabilkan nilai $\mathrm{pH}$ nutrisi yang di kontrol supaya daya pancar / buka tutupnya solenoid valve sesuai dengan yang diperlukan.

\subsection{Pengujian Sensor $\mathrm{pH}$}

Di dalam pengujian sensor $\mathrm{pH}$ tipe SEN0169 dibandingkan dengan Digital pH meter, adapun hasilnya seperti yang ditunjukkan tabel di bawah ini:

Tabel 4 Perbandingan pembacaan sensor dan digital $\mathrm{pH}$

\begin{tabular}{|l|c|c|c|}
\hline Jenis Cairan & Digital $\mathrm{pH}$ meter & Sensor pH SEN0169 & Error (\%) \\
\hline Larutan Nutrisi & 7,1 & 7 & 1,4 \\
\hline $\mathrm{pH}$ buffer 6,86 & 6,6 & 6,5 & 1.5 \\
\hline $\mathrm{pH}$ Buffer 4,01 & 4 & 4 & 0 \\
\hline Cairan $\mathrm{pH}$ down & 0 & 0 & 0 \\
\hline \multicolumn{3}{|c|}{ Rata - rata Error } & 0,7 \\
\hline
\end{tabular}




\subsection{Pengujian Fuzzy Logic Controller}

Di dalam pengujian Fuzzy logic controller difokuskan untuk melihat dan menganalisa pada waktu menaikkan nilai $\mathrm{pH}$ dari $5 \mathrm{ppm}$ menuju setting point 7 dan menurunkan nilai $\mathrm{pH}$ dari ppm nutrisi 9 menuju setting point 7.

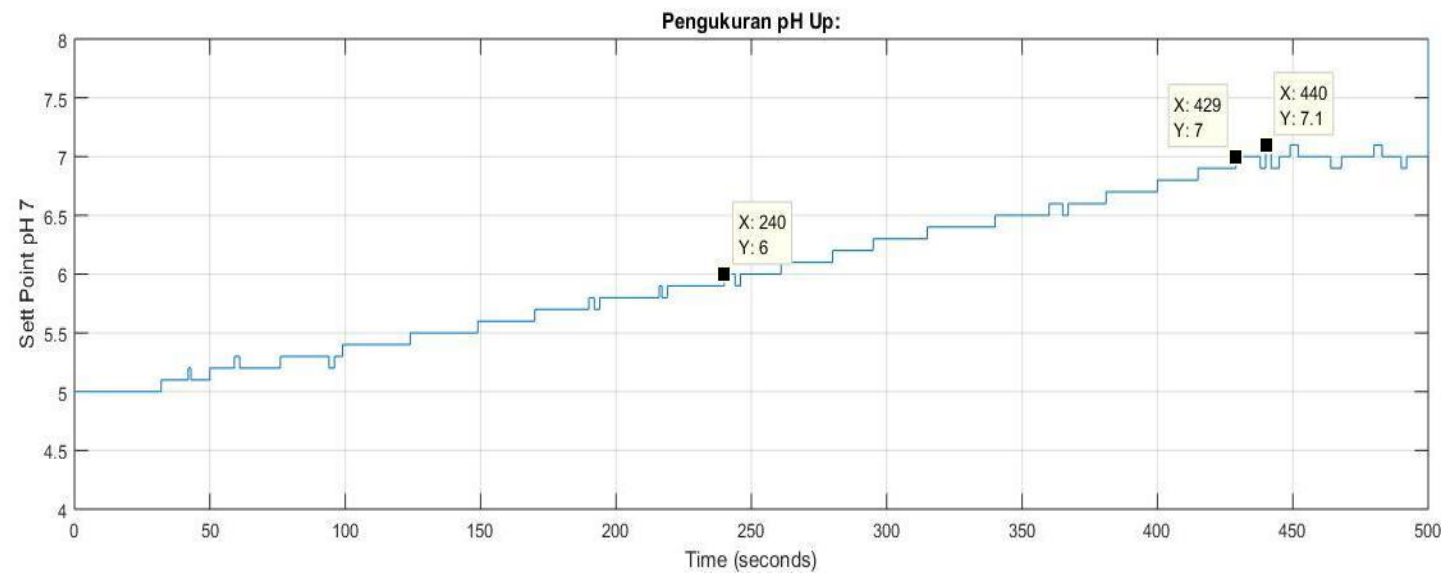

Gambar 13 Pengukuran nutrisi pH naik

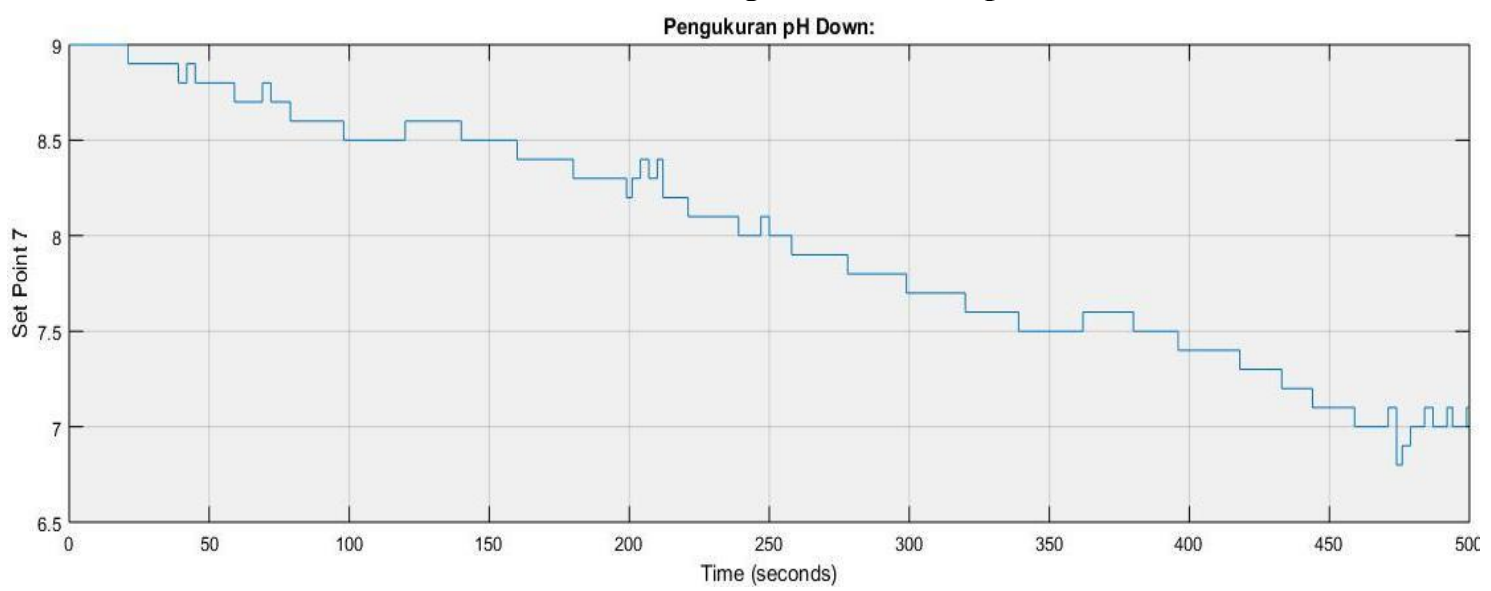

Gambar 14 Pengukuran nutrisi pH turun

Dari hasil pengontrolan fuzzy logic untuk pH naik dari ppm 5 ke 7 (Gambar 13) didapatkan nilai tunda sebesar : 240 detik, waktu naik : 429 detik, steady state : 452 detik dan nilai overshoot :1.4\%. Pengontrolan pH turun dari ppm 9 ke 7 ( Gambar 14 ) didapatkan nilai tunda sebesar : 239 detik, waktu naik : 459, steady state : 479 dan nilai overshoot : $1.4 \%$.

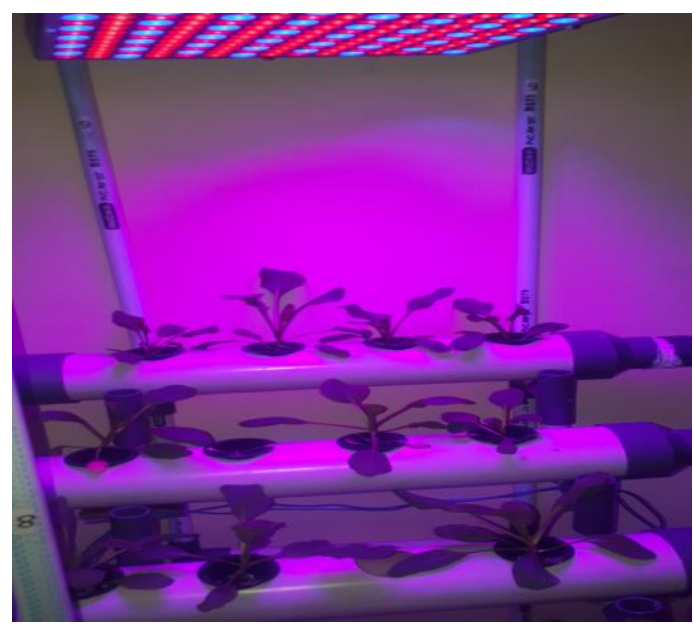

Gambar 15 Sistem Hidroponik 


\section{KESIMPULAN}

Berdasarkan hasil perancangan, pengujian, dan analisa pada "Desain Kontrol Sistem Telemetri pH Larutan Nutrisi Hidroponik Berbasis Fuzzy Logic", dapat di tarik kesimpulan sebagai berikut : Telah berhasil dikembangkan sebuah sistem yang dapat memantau dan mengendalikan dari jarak jauh untuk pengukuran $\mathrm{pH}$ larutan nutrisi hidroponik berbasis Fuzzy Logic". Sistem dapat mengukur pH 5 - 7 dengan karakteristik tunda 240 detik, waktu naik 429 detik, steady state 452 detik dan overshoot $1.4 \%$. Pengontrolan $\mathrm{pH}$ turun dari 9 ke 7 ppm dengan karakteristik waktu tunda 239 detik, waktu naik 459 detik, steady state 479detik dan overshoot $1.4 \%$.

\section{SARAN}

Penelitian ini masih bisa dikembangkan dengan model IoT dan skala yang lebih besar / luas untuk dunia industri.

\section{DAFTAR PUSTAKA}

[1] Helmy. et al. "Nutrient Film Technique (NFT) Hydroponic Monitoring System”. JAICT ( Journal of Applied Information and Communication Technologies). Vol.1, No.1. 2016

[2] S. Lee and L. Lee. "Beneficial bacteria and fungi in hydroponic systems: Types and characteristics of hydroponic food production methods",. The Ohio State University, Columbus, OH, USA., vol. 195, pp. 206-215. 2015

[3] D. Pancawati dan A. Yulianto, "Implementasi Fuzzy Logic Controller untuk Mengatur pH Nutrisi pada Sistem Hidroponik Nutrient Film Technique ( NFT ). Universitas Internasional Batam. JNTE. Vol: 5, No. 2. ISSN: 2302 - 2949. 2016

[4] C. B. D. Kuncoro, T. Sutandi, and M. A. Falahuddin, "The Development of the nutrient solution cooling system for The Hydroponic cultivation". Politeknik Negeri Bandung. 2017

[5] Sung, W. et al. "Multi-Sensors Data Fusion Based on Arduino Board and XBee Module Technology". International Symposium on Computer, Consumer and Control. IEEE. 2014

[6] M. Fakhruzzaini dan H. Aprilianto, "Sistem Otomatisasi Pengontrolan Volume dan PH Air Pada Hidroponik,” JUTISI Vol. 6, No. 1: 1311 - 1448. ISSN: 2089-3787. 2017

[7] G. G. Heliadi et al., "Monitoring and Control of Nutrition on NFT Hydroponic System Based on Electrical Conductivity," vol. 5, no. 1, pp. 885-893, 2018.

[8] M. Telaumbanua, B. Purwantara, dan L. Sutiarso. "Rancang Bangun Aktuator Pengendali Iklim Mikro di dalam Greenhouse untuk Pertumbuhan Tanaman Sawi". Fakultas Teknologi Pertanian, UGM Yogyakarta, AGRITECH, Vol. 34, No. 2, Mei. 2014

[9] H. Abbas, R. Syam dan B. Jaelani. "Rancang Bangun Smart Greenhouse Sebagai Tempat Budidaya Tanaman Menggunakan Solar Cell Sebagai Sumber Listrik". Proceeding Seminar Nasional Tahunan Teknik Mesin XIV (SNTTM XIV). 2015

[10] T.M.P. Dyka. "Pengendalian pH dan EC pada Larutan Nutrisi Hidroponik Tomat Ceri". Institut Bisnis dan Informatika Stikom Surabaya. 2018 